\title{
The effects of School location on students' academic achievement in senior secondary physics based on the $5 E$ learning cycle in Delta State, Nigeria
}

\author{
Ikechuku Abamba \\ State University, Abraka, Nigeria
}

This study examined the effects of school location on secondary school students' academic achievement in Physics based on the 5E learning cycle. The design of the study was a non - randomized prêt-test, post-test control group quasiexperimental design. The population of the study was 66,345 . Two hundred and forty-three students were sampled from six schools. Four hypotheses were tested at 0.05 level of significance. The hypotheses state that there is no significant difference in mean achievement scores in Physics between urban and rural students taught using $5 \mathrm{E}$ leaning cycle among others. The statistical tools used were mean, standard deviation and Analysis of Covariance (ANCOVA) were used in testing the hypotheses formulated. The result amongst others showed there is no significant difference between rural and urban students' achievement taught using $5 \mathrm{E}$ learning circle (Fcal. (113) $=\mathrm{F}$ crit (0.005), $\mathrm{p}>0.05)$. Based on the findings, it was recommended among others, that $5 \mathrm{E}$ learning cycle be adopted in Nigeria secondary schools as a teaching method and that faculties of education in various schools of higher learning should ensure that $5 \mathrm{E}$ learning cycle is included as a method of teaching Physics

\author{
Article Details \\ LUMAT General Issue \\ Vol 9 No 1 (2021), 56-76 \\ Received 28 May 2020 \\ Accepted 5 February 2020 \\ Published 19 February 2021 \\ Pages: 21 \\ References: 35 \\ Correspondence: \\ abambai@yahoo.com \\ https://doi.org/10.31129/ \\ LUMAT.9.1.1371
}

Keywords: school location, 5E learning cycle, physics, interaction effects and students achievement

\section{Introduction}

The International Union of Pure and Applied Physics (IUPAP) defines Physics as the scientific study of matter and energy and their interactions with each other, which plays a key role in the future process of mankind. Advancement in physics often translates to the technological sector and, sometimes to the other sciences, Mathematics and Philosophy (IUPAP, 1999). For instance, advancement in Physics, relative to electromagnetism, has led to the spread of electrically driven devices; advancement in thermodynamics has led to the development of motorized transport; just as advancement in mechanics has also led to the development of calculus, quantum chemistry, and the use of instruments such as electron microscope in microbiology. Okoronta (2004) asserts that Physics is a vehicle for achieving long-term goals of science because it is instrumental to technological and socio economic growths across the globe. Physics, as a subject, is the foundation 
upon which the scientific and technological advancement of a nation rests (Ogunleye \&Babajide, 2011). It is the link between all the science subjects at the secondary school level and technological courses at the tertiary levels of education.

In spite of the importance of Physics, its teaching and learning have been in decline in Nigeria as shown by its low enrollment. The reason is not far-fetched. Ogunleye and Babajide (2011) state that there are observable problems plaguing the learning of Physics in Nigeria. They include poor infrastructure, lack of qualified manpower, non - availability of, or poorly equipped laboratories, wrong teaching methods, among others. Such problems often lead to students' poor performance in external examinations, such as the West African Examination Council (WAEC) or Joint Admission and Matriculation Board (JAMB), (Abamba, 2012)

Research by Ogunleye and Babajide (2011) affirm that Physics students at the secondary school level continue to exhibit poor performances in the subject. The methods of teaching adopted by teachers go a long way in determining how students learn, and this ultimately affects their academic achievement. Eze (2003) blames the persistent low achievement on persistent use of traditional teaching methods, especially the lecture method which has been very ineffective in teaching pedagogy. Hence, Eze (2003) advocate a shift from the traditional methods to more effective ones that will engage the students' domains (affective, cognitive and psychomotor) of learning. Teaching is not just a process of passing information by the teacher or showing how much a teacher can express himself but one that affords students the opportunity to interact with both humans and available material resources. Agbowaro (2008) states that meaningful learning is active, constructive, intentional, authentic and cooperative. Therefore, it is imperative for teachers to employ methods that are student-centered. According to Bybee, Tylor, Gardner, Scaffer, Powell, Westbrook and Landes (2006), science teachers' globally strive to improve their instructional practices to enhance students' learning. According to them, science teachers, curriculum experts have identifying research findings to incorporate into materials in order to facilitate connections between the teachers, the curriculum, and the students. Bybee et al. (2006) state that the use of coherent and coordinated sequencing of lessons and instrument models have become popular in science education at present. 


\subsection{Origin and development of $5 \mathrm{E}$}

The $5 \mathrm{E}$ learning cycle is an instructional model that describes a teaching sequence that can be used for an entire program, specific units and individual lessons. It was developed by the Biological Science Curriculum Study (BSCS) through a team led by Roger Bybee in the late 1980's from the work of Atkin and Karplus who explored children thinking and their explanation of natural phenomena. By 1961, Karplus began connecting the developmental psychology of Jean Piaget to the design of instrumental material and science teaching. In 1901, J.M. Atkin shared Karplus' ideas about the teaching of science to young children. Their collaboration led to the development of a model of guided discovery that focused on exploration, invention, and discovery (Bybee et al., 2006; Kolis, Krusack, Stombaugh, Stow and Brenner, 2010; Ajaja and Eravwoke, 2012). In the 1980's, Lawson and others slightly modified the terms of the Atkin and Karplus model, though, in spite of the changes, the conceptual foundation of the learning cycle remained the same. According to Bybee, the new phases added to the SCS model are engagement and evaluation. The $5 \mathrm{E}$ learning cycle has become successful in improving students' achievement in science and in helping to improve the way students learn. According to Bybee (2011), the $5_{\mathrm{E}}$ learning cycle has been more successful than was imagined when it was originally developed and it is recognized internationally and applied in other disciplines other than science; adapted by curriculum developers outside the BSCS, and used by science teachers at all levels.

The $5 \mathrm{E}$ learning cycle consists of 5 stages which are engagement, exploration, explanation, extension and evaluation in that order.

1. Engagement: the teacher assesses the learners' prior knowledge, helps in engaging them in a new concept, using short activities in promoting curiosity and eliciting prior knowledge. According to them, such activities should connect past and present learning experiences, reveal prior conceptions, and organize students' thinking in achieving the learning outcomes of current activities (Bybee, 2011).

2. Exploration: this stage provides students with a common experience within which current concepts, processes and skills are identified and a conceptual change is facilitated. Learners may complete laboratory excise that allows them to use prior knowledge in generating new ideas, exploring possibilities and questions, designing and conducting preliminary investigations (Bybee, 2011). 
3. Explanation: this stage focuses on students' attention on their engagement and exploration experiences, and enables them to demonstrate an understanding of concepts, process skills or behaviour (Bybee, 2011). It enables teachers to directly introduce concepts, processes or skills. Learners are allowed to explain their understanding of the concepts. The teacher's explanation or the curriculum may guide students towards a deeper understanding of the concept.

4. Extension (elaboration): teachers challenge and extend students conceptual understanding and skills. Through new experiences, students develop deeper and broader understanding, acquire more information, adequate skills, and apply their understanding of the concept by conducting additional activities (Bybee, 2011). Students conduct additional activities based on their new experiences.

5. Evaluation: according to Bybee et al. (2006), evaluation stage encourages students to assess their understanding and ability and provides opportunities for teachers to evaluate students' progress towards achieving the educational objectives. It is a diagnostic process which enables the teacher to determine whether the learner has attained understanding of concepts knowledge.

Since the development of $5 \mathrm{E}$ learning cycle, a lot of researches have been carried out to examine the instructional effectiveness of learning across different subjects in the sciences. Adams, Bevevino \& Dangel (1992) explored the $5 \mathrm{E}$ learning cycle model approach and found that it encourages students to develop their own frame of thought. Caprio (1994) compared a class taught with traditional method in 1985 with one taught with $5 \mathrm{E}$ instructional model and found that the students taught by using $5 \mathrm{E}$ instructional model achieved higher.

Some studies conducted by using $5 \mathrm{E}$ instructional model revealed that the model increases the success of students, improves conceptual understanding and their attitudes (Kor, 2006 \& Saglan, 2006 in Cardak et al., 2008). In another study, Seyhan \& Morgil (2007) compared two classes taught with traditional methods with two classes taught with the $5 \mathrm{E}$ instructional method. They found that the experimental group had a much greater understanding of information, especially on questions that required interpretation. Keser \& Akdeniz (2010) stated that the ${ }_{5} \mathrm{E}$ learning cycle aids the teacher to structure and sequence potential learning experiences in a systematic and synergistic way that is consistent with a constructivist view of teaching and learning. They further said that the $5 \mathrm{E}$ learning 
cycle is not an essential part of students' learning but a scaffold or framework for the teacher. Hence, students must be provided with learning environments that encourage them to explain their ideas and understanding and give opportunity for them to extend their knowledge of concepts to other contexts (Boddy et al., 2003).

Cepni, Sahin \& Ipek (2010) showed that instructional materials embedded with different techniques in the $5 \mathrm{E}$ learning cycle could be effective in removing alternative conceptions and providing conceptual changes more than existing material. Turki \& Calik (2008) also found that students were highly motivated and their achievement were increased when $5 \mathrm{E}$ learning cycle model was employed in the teaching of exothermic and endothermic reactions. Tuna \& Kacar (2013) observed students' scores in experimental group on academic achievement and permanence on trigonometry knowledge are higher than those of the control group statistically when $5 \mathrm{E}$ learning cycle was employed. The difference between the groups is statistically significant and in favour of the experimental group. Abdul, Muhammad, Khalid \& Shahid (2010) worked on the teaching of Physics with the $5 \mathrm{E}$ learning cycle model. The study was aimed at measuring the effectiveness of the $5 \mathrm{E}$ learning cycle based on the constructivist approach in the teaching of Physics in public secondary schools. Results showed that the achievement level of students had a significant difference from the performance of students taught with traditional methods. They concluded that the instruction based on $5 \mathrm{E}$ learning cycle model yielded better student' performance than that of students taught by the lecture method. Ajaja \& Eravwoke (2012) showed that students taught by using the learning cycle had a better achievement in Biology and Chemistry compared to their counterparts that were taught by the lecture method. Similarly, Balci, Cakiroglu \& Tekkaya (2006) compared the effectiveness of $5 \mathrm{E}$ learning cycle with expository instructions and found that the activities of students in $5 \mathrm{E}$ learning cycle activated their prior knowledge and to overcome struggling with their misconceptions.

Ajaja (2013) showed that students in the $5 \mathrm{E}$ learning cycle and cooperative learning group significantly outscored those in the concept mapping and lecture group on both achievement and retention tests. Furthermore, students in $5 \mathrm{E}$ learning cycle and cooperative learning groups did not significantly differ on achievement and retention. Qarareh (2012) also observed that students taught by the use of the $5 \mathrm{E}$ learning cycle achieved better results than students in the group that was taught with the traditional method. 


\subsection{Limitations}

However, since the application of $5^{\mathrm{E}}$ learning cycle in the teaching/learning process, a rage limitation has been observed. One such limitation is that teachers have been finding it difficult to use the model effectively such that major characteristics of the model are overlooked (Keith \& Shelly, 2012). In addition to this, not extending the elaboration into novel areas beyond the specific concept has been identified educator using only verbal explanation during the $3^{\text {rd }}$ stage (explain) has also been criticized (Keith et al., 2012; Fletcher in Somayeh \& Shahram, 2015). Hence, researchers have called for proper training of both instructors and students before the commencement of instruction (Ajaja, 2013).

The model has also been criticized for being time-consuming both in implementation and in planning, with calls for increased time on the task before and during instruction (Ajaja, 2013; Claire, 2013). Kirschner et al. (2006) and Dodge, (2017) also observed the risk of developing new misconceptions by students with little background or experience in the concept. Furthermore, Ajaja (2012) observed that low ability students may find it very difficult to cope with the model and called for strong cooperation among members of a group under such program. Finally, the bulk of the limitations highlighted stern from the fact that most educators find $5 \mathrm{E}$ learning cycle novel and thus lack the skill required for the effective use of the model. There must be adequate tutelage for both instructors and students on their level of participation in all 5 stages of instruction

\subsection{Urban and rural schools}

The location of a school has a big role to play in the academic achievement of students at school. Akinyele (2011) stated that the immediate environment of a child plays a major role in his socialization. According to him, the area in which a school is located can affect the academic achievement of a student. In the same vein, Akpan (2001) has stated that school location is one of the major factors that affect students' academic achievements. A school located in a rural area is usually faced with problems like shortage of teachers, lack of laboratories, poorly equipped laboratories, among others in Nigeria. These shortcomings negatively affect both students' motivation and achievement. Evidence abound that the educational aspirations of students who study in rural are weaker than those of their urban counterparts (Hum, 2003; Arnold et al., 2005). Macmillan (2012) found that students in rural areas place less value on studies such that their achievements are 
affected.

Adesoji and Olatunbosun (2008) have pointed out that the relationship between the location of a school and students' academic achievements has been reported. Urban students perform better than their counterparts in semi-urban and rural schools (Adepoju, 2001; Ogunleye, 2002; Ndukwu, 2002). Corroborating this, $\mathrm{Hu}$ (2003) said that, compared with urban students, rural students tend to have lower educational aspiration, place less values on academics, and have lower academic motivation. Owoeye (2002) found a significant difference between the academic performance of students in rural areas and that of their urban counterparts.students in urban areas are better.

On the other hand, Ajayi (1999) studied the relationship between academic achievement and school location and found that the there is no significant difference between academic achievement of students in urban students and that of students in rural students. Yusuf and Adigun (2010) also observed that whether a student attends a rural or urban secondary school does not make any difference in his academic achievement. Owoeye and Yara (2011) posit that in Nigeria, education in rural areas is usually full of difficulties.

1. Teachers who are qualified don't like being posted to villages

2. Villagers prevent their children from going to school regularly because of the children's involvement in farming activities

3. Parents are reluctant to entrust their female wards to male teachers.

4. Lack of roads and communication facilities making it difficult to get books and teaching materials to the schools.

There is, therefore, disparity between the quality of teachers in urban schools and that of those in rural areas, and, this is reflected in students' achievement. The review has shown that more researchers hold the view that urban students do better than rural ones. This research is, therefore, designed to investigate whether the application of $5 \mathrm{E}$ learning cycle will significantly improve the achievement of students both in rural schools and urban schools irrespective of the location of the school.

Having established that students' academic achievement in the sciences, particularly in Physics is, in decline, it has become imperative to find methods and strategies that can curb this downward trend in students' achievement in that subject. Having examined the effectiveness of the $5_{\mathrm{E}}^{\mathrm{E}}$ learning cycle in improving students' achievement in the learning of science subjects, and having and seeing the 
poor achievement in the rural areas, this work therefore seeks to examine the effects of school location on students' achievement in Physics based on the $5 \mathrm{E}$ learning cycle. The general purpose of this study is to examine the effects of school location on students' academic achievement based on the $5^{E}$ learning cycle. Specifically, the study will find out whether

1. There is a difference in the mean achievement scores in Physics between urban and rural students taught with the 5 E learning cycle model.

2. There is a difference between the mean achievement scores of urban and rural secondary school students taught with the lecture method.

\section{Research hypotheses}

The following null $\left(\mathrm{H}_{\mathrm{o}}\right)$ hypotheses were put forward to answer the problems stated and tested at 0.05 level of significance

1. $\mathrm{Ho}_{1}$ : there is no significant difference in the mean achievement scores of students in Physics between groups taught by the $5 \mathrm{E}$ learning cycle and those taught with lecture method.

2. $\mathrm{Ho}_{2}$ : there is no significant difference in the mean achievement scores in Physics between urban and rural students taught with $5 \mathrm{E}$ learning cycle model.

3. $\mathrm{Ho}_{3}$ : there is no significant difference in the mean achievement scores in Physics between urban and rural students taught with the lecture method.

4. $\mathrm{Ho}_{4}$ : there is no significant interaction effect between method and school location on students' academic achievements in Physics.

\section{Materials and methods}

\subsection{Design of the study}

A research design is the plan or logical structure of a study (Okorodudu, 2013). According to him, the nature of the problem and the hypotheses to be tested as well as the type of sample and the subjects determine to a large extent the design to be adopted. The study is a non-randomized pre-test, post-test control group quasiexperimental design. The population of the study is sixty-six thousand, three 
hundred and forty-five $(66,345)$. Two hundred and forty-six students were sampled using simple random sampling technique from six secondary schools in Delta State (two from each senatorial district out of the three senatorial districts) using stratified sampling.

\subsection{Instrumentation}

The research instruments designed by the researcher and used for this study include

1. Physics Achievement Test (PAT). The test was constructed by the researcher on topics in the concept of light waves. The topics treated include reflection of light waves, refraction of light waves and applications of light waves. The test consisted of 50 multiple-choice questions with options A-D or E from past West African Examination Council (WAEC) questions. A table of specification prepared showed that $48 \%$ of the question tested their knowledge of the concepts, $36 \%$ tested comprehension, and $16 \%$ tested application of the concepts.

2. Instructional packages for the instructors (lesson play). They include (a) comprehensive lesson plan on $5 \mathrm{E}$ learning cycle on the concept of light waves (b) comprehensive lesson plan based on the traditional method (lecture method).

\subsection{Validity and reliability}

Factor analysis is a statistical method used to describe variability among observed correlated variables in terms of a potentially lower number of unobserved variables called factors. The Physics Achievement Test (PAT) was administered to 31 participants who were involved in the pilot test. The instrument was found valid in content, construct and face. In establishing the reliability of the instrument, KuderRichardson formula 21 ( $\mathrm{KR} 2_{1}$ ) was used to estimate the internal consistency reliability of PAT. KR21 coefficient calculated was 0.71. Based on this value, the Physics achievement test was found reliable. The factor analysis of items in Physics Achievement Test (PAT) was processed so that the test could be estimated for content and construct validity. The factor analysis of the PAT began with the processing of Descriptive Statistics and Initial Communalities. The Descriptive Statistics of mean and standard deviation of total items retained for the 31 (intact 
class) participants who were involved in the pilot test of the PAT instrument at Delta State University Secondary School were reported. A total of 50 items were selected out of the initial total items of 78 that were factor analysed. These 78 items selected were computed for content and construct validity using Factor Analysis Output from principal component analysis (PCA).

To establish the content validity of the instrument, Eigen value of above 1 was used to select factor components into the PAT instrument. The factor matrix of all factors or components had to be rotated to determine the weight of each item within each of the components. The cumulative variance for all rotated sums of squared loading was estimated as $89.45 \%$. This is an indication of the content validity of PAT. It revealed that PAT covered up to $89.45 \%$ of the domain of Physics Achievement Variable with a total of unexplained variance of $10.55 \%$. Therefore, on the whole, the cumulative Eigen value of $89.45 \%$ is above $50 \%$ and hence the PAT was considered content valid.

In establishing the construct validity, the factor matrix of all factors or components had to be rotated using Varimax to determine the weight of each item within each of the components. Eigen value of above 1 was used to select factors that genuinely measure similar construct. From the observed scores, latent variables were identified with the number of items measured by the construct. Since rotated factor loading matrixes range between 0.29 and 0.81 , it can be concluded that PAT has construct validity.

The Physics Achievement Test, after selection, was given to three experts in science education to establish the face validity of the instrument.

\subsection{Treatment procedure}

- Training of instructors

The physics teachers used for the experimental group were trained on the skills of using $5_{\mathrm{E}}$ learning cycle for teaching. This exercise lasted for three days (a day was devoted to a teacher in a school). The process started with explaining the meaning of $5 \mathrm{E}$ learning cycle, its origin, modifications and applications in the teachinglearning process. The next stage was done using the $5 \mathrm{E}$ training manual adopted from SEDL (2012), explaining the role of teachers and students on every stage of the model. 
- Treatment proper

The researcher obtained an official permission from the heads of the six (6) secondary schools for the study. The Physics teachers in each school were used as research assistants. Where the school has more than one Physics teacher, the research assistant was the teacher assigned to Senior Secondary 11 (SSII). The researcher gave them orientation on the purpose of the study to ensure uniformity and ensure that each conformed to the content and method assigned. For the research assistants in the experimental groups, the researcher explained how to follow up the students at every stage and guide their transition to the next stage of instruction based on the $5 \mathrm{E}$ learning cycle. The researcher explained the kind of questions to be asked at different stages of the cycle. The level of their involvement at every stage was also explained to the teachers. The researcher embarked on several supervision visits to the schools to check on the effectiveness of the teachers with respect to the treatment procedure assigned to that school.

At the end of the orientation exercise, the research assistants for the experimental groups were handed a copy of the instructional lesson plans based on the $5 \mathrm{E}$ instructional model and the necessary instructional materials for the instructions to commence. In addition, copies of lesson plans for the control groups as well as the necessary instructional materials were given to the assistants in order to commence teaching.

The researcher visited each school before the commencement of instruction, and administered the test (Physics Achievement Test, PAT) with the assistance of the research assistants in each school. The students were given the necessary instructions and asked to answer the questions within specified time frame. After the test, the researcher retrieved the answer sheets and the question papers from them and marked. This accounted for the pre-test scores. Also, the researcher handed the test (PAT) to the research assistants a week to the end of the program to administer to the students within three days after instruction has been concluded. They were collected back by the researcher for marking. This accounted for the posttest scores. 


\subsection{Method of data analysis}

The data obtained were analysed using descriptive statistics (mean and standard deviation) while hypothesis 1, 2 and 3 were tested using the Analysis of Covariance (ANCOVA).

\section{Results and Discussions}

Data gathered were analysed and the results are presented below.

\subsection{Test of assumptions}

The following tests of assumptions were established to justify the use of ANCOVA.

1. The covariate was measured before treatment

2. The Crombach alpha using the reliability procedure was established

3. More than one covariate were used

4. The linearity was established. The straight line shows a linear relationship with each other.

5. The significant interaction between the covariate and the treatment is 0.4. This is above 0.05 level of significance, thus, establishing the homogeneity of regression slope.

\subsection{Test of hypotheses}

- Result on hypothesis 1

The hypothesis examined whether there is no significant difference in the mean achievement scores of students in Physics between groups taught by using $5 \mathrm{E}$ learning cycle and those taught by using the lecture method.

From table 1, the experimental group had a mean achievement score of 25.50 while that of control group had a mean achievement of 15.25 in post-test score over 50. The difference in mean achievement is 10.25. Also, the standard deviation for post-test experimental group is 5.16 while that of control is 3.19. This shows that there is a difference in the mean achievement in favour of the experimental group. 
An inferential statistics will be used to establish whether the difference is statistically significant.

Table 1. Mean and standard deviation (SD) of both experimental and control groups.

\begin{tabular}{lllll}
\hline Test & $\begin{array}{l}\text { Teaching } \\
\text { Method }\end{array}$ & $\mathbf{N}$ & Mean & SD \\
\hline \multirow{2}{*}{ Pretest } & 5E model & 113 & 8.86 & 3.15 \\
& Lecture & 133 & 8.64 & 3.18 \\
\multirow{2}{*}{ Posttest } & 5E model & 113 & 25.50 & 5.16 \\
& Lecture & 133 & 15.25 & 3.19 \\
\hline
\end{tabular}

Analysis of covariance (ANCOVA) was carried out to determine the difference is significant and the result is presented in table2.

The result of the ANCOVA gives an $F(246)=360.591$ which is significant at 0.05 level of significance. This implies that there is a statistically significant difference in the achievement of the groups. From the result, there are enough reasons to reject hypothesis 1 . Therefore, there is a significant difference in the mean achievement scores of students taught using $5 \mathrm{E}$ learning cycle and those taught by using the lecture method in Physics. Furthermore, the value of Adjusted $R$ Squared is 0.596 . This implies that the $5 \mathrm{E}$ learning cycle contributed $59.6 \%$ to the achievement of students.

Table 2. Summary of analysis of covariance (ANCOVA) for the significance of difference in physics test scores between students exposed to $5 E$ learning cycle and lecture method.

Dependent variable: post-test

\begin{tabular}{llllll}
\hline Source & $\begin{array}{l}\text { Type III Sum of } \\
\text { Squares }\end{array}$ & Df & \multicolumn{2}{l}{ Mean Square $\boldsymbol{F}$} & Sig. \\
\hline Corrected Model & $6441.352^{\mathrm{a}}$ & 2 & 3220.676 & 182.041 & .000 \\
Intercept & 10724.767 & 1 & 10724.767 & 606.193 & .000 \\
Pretest & 25.904 & 1 & 25.904 & 1.464 & .227 \\
Treatment & 6379.578 & 1 & 6379.578 & 360.591 & .000 \\
Error & 4299.156 & 243 & 17.692 & & \\
Total & 108701.000 & 246 & & & \\
Corrected Total & 10740.508 & 245 & & & \\
\hline
\end{tabular}

a. $R$ Squared $=.600$ (Adjusted $R$ Squared $=.596$ )

- Result on hypothesis 2

Hypothesis 2 examined whether there is no significant difference in the mean achievement scores in Physics between urban and rural students taught by using ${ }_{5} \mathrm{E}$ learning cycle. 
Table 3 shows the mean achievement of rural and urban students in pre-tests are 9.18 and 8.87 with a standard deviation of 3.25 and 2.85 over 50 respectively. The post test scores are 25.57 and 25.32 while the standard deviations are 5.88 and 4.64 respectively. From the result of the discipline statistics, there is a difference in the mean achievement scores in Physics between rural and urban students taught by using 5 E learning cycle method.

Table 3. Mean and standard deviation between urban and rural students taught using 5E learning cycle.

\begin{tabular}{lllll}
\hline Test & $\begin{array}{l}\text { School } \\
\text { location }\end{array}$ & $\mathbf{N}$ & Mean & SD \\
\hline \multirow{2}{*}{ Pre-test } & Rural & 44 & 9.18 & 3.25 \\
& Urban & 62 & 8.87 & 2.85 \\
\multirow{2}{*}{ Post-test } & Rural & 47 & 25.57 & 5.88 \\
& Urban & 62 & 25.32 & 4.64 \\
\hline
\end{tabular}

When subjected to inferential statistics using ANCOVA, the result is presented in table 4. The ANCOVA result reveals that $\mathrm{F}(113)=0.004$ is not significant at 0.05 level of significance. This result shows that the $\mathrm{F}-$ ratio of 0.004 is not statistically coefficient. This implies that there is no statistically significant difference in the achievement of urban and rural students taught by using 5 Elearning cycle.

Table 4. Result of analysis of covariance (ANCOVA) of test scores between urban and rural students on achievement in groups taught using $5 \mathrm{E}$ learning cycle

Dependent variable: post-test

\begin{tabular}{lllllll}
\hline Source & $\begin{array}{l}\text { Type III Sum of } \\
\text { Squares }\end{array}$ & $\begin{array}{l}\text { Mean } \\
\text { Square }\end{array}$ & $F$ & Sig. & $\begin{array}{l}\text { Partial Eta } \\
\text { Squared }\end{array}$ \\
\hline Corrected Model & $7.571^{\mathrm{a}}$ & 2 & 3.785 & .140 & .870 & .003 \\
Intercept & 6622.269 & 1 & 6622.269 & 244.723 & .000 & .690 \\
Prettest & 7.350 & 1 & 7.350 & .272 & .603 & .002 \\
Location & .097 & 1 & .097 & .004 & .952 & .000 \\
Error & 2976.624 & 110 & 27.060 & & & \\
Total & 76590.000 & 113 & & & & \\
Corrected Total & 2984.195 & 112 & & & & \\
\hline
\end{tabular}

a. $R$ Squared $=.003$ (Adjusted $R$ Squared $=.016$ )

- Result on hypothesis 3

Hypothesis 3 examined whether there is no significant difference in the mean achievement scores in Physics between urban and rural students taught by using the 
lecture method. Table 5 shows the mean achievement scores for rural and urban students in pre-test are 9.74 and 8.48 respectively, while the post test scores are 13.75 and 15.67 over 50 respectively. From the result of the description statistics, there is a difference in the mean scores in Physics between rural and urban students taught by using the lecture method.

Table 5. Mean and standard deviation between urban and rural students taught using lecture method.

\begin{tabular}{lllll}
\hline Test & $\begin{array}{l}\text { School } \\
\text { location }\end{array}$ & N & Mean & SD \\
\hline \multirow{2}{*}{ Pretest } & Rural & 34 & 9.74 & 3.57 \\
& Urban & 84 & 8.48 & 2.92 \\
\multirow{2}{*}{ Posttest } & Rural & 34 & 13.71 & 3.58 \\
& Urban & 84 & 15.67 & 3.04 \\
\hline
\end{tabular}

In determining whether the difference was significant, ANCOVA was employed. The result of $F(133)=2.914$ is not significant at 0.05 level of significant. This implies that there is no statistically significant difference in the achievement of urban and rural students taught with the lecture method. Therefore hypothesis 3 is accepted.

Table 6. Result of analysis of covariance (ANCOVA) of test scores between urban and rural students on achievement in groups taught using lecture method

Dependent Variable: Post-test

\begin{tabular}{lllllll}
\hline Source & $\begin{array}{l}\text { Type III Sum } \\
\text { of Squares }\end{array}$ & Df & $\begin{array}{l}\text { Mean } \\
\text { Square }\end{array}$ & $\boldsymbol{F}$ & Sig. & $\begin{array}{l}\text { Partial Eta } \\
\text { Squared }\end{array}$ \\
\hline Corrected Model & $36.258^{\mathrm{a}}$ & 2 & 18.129 & 1.790 & .171 & .027 \\
Intercept & 3017.837 & 1 & 3017.837 & 298.013 & .000 & .696 \\
Prettest & 10.246 & 1 & 10.246 & 1.012 & .316 & .008 \\
Location & 29.508 & 1 & 29.508 & $\mathbf{2 . 9 1 4}$ & .090 & .022 \\
Error & 1316.449 & 130 & 10.127 & & & \\
Total & 32398.000 & 133 & & & & \\
Corrected Total & 1352.707 & 132 & & & & \\
\hline
\end{tabular}

a. R Squared $=.027$ (Adjusted R Squared $=.012$ )

- Result on hypothesis 4

In determining the interaction between methods and location, ANCOVA interaction table was employed and the result is presented in table 7 .

Table 7 shows $\mathrm{F}(228)=\mathbf{2 . 1 7 8} ; \mathrm{P}>0.141$ which reveals that there is no interaction effect between method and location on students achievements in Physics. This 
implies that the factors could not interact to affect the achievement of students in Physics.

Table 7. Summary of ANCOVA for significant interaction effect between the methods used and school location on achievement in Physics.

Tests of Between-Subjects Effects

Dependent Variable: post-test

\begin{tabular}{llllll}
\hline Source & Type III Sum of Squares & Df & Mean Square & $F$ & Sig. \\
\hline Corrected Model & $6511.513^{\mathrm{a}}$ & 4 & 1627.878 & 92.769 & .000 \\
Intercept & 9305.457 & 1 & 9305.457 & 530.295 & .000 \\
Pretest & 47.818 & 1 & 47.818 & 2.725 & .100 \\
Treatment & 6361.421 & 1 & 6361.421 & 362.522 & .000 \\
Location & 30.128 & 1 & 30.128 & 1.717 & .191 \\
treatment * location & 38.219 & 1 & 38.219 & 2.178 & .141 \\
Error & 4228.995 & 241 & 17.548 & & \\
Total & 108701.000 & 246 & & & \\
Corrected Total & 10740.508 & 245 & & &
\end{tabular}

R Squared $=.606$ (Adjusted R Squared $=.600$ )

The graph of interaction in figure 1 shows an ordinary interaction because the lines does not cross each order. From table 7, F-cal (2.178)> F-crit (3.84) shows that there is no significant interaction effect between method and location on student achievement in Physics. Thus, the null hypothesis of non significant interaction effect was accepted.

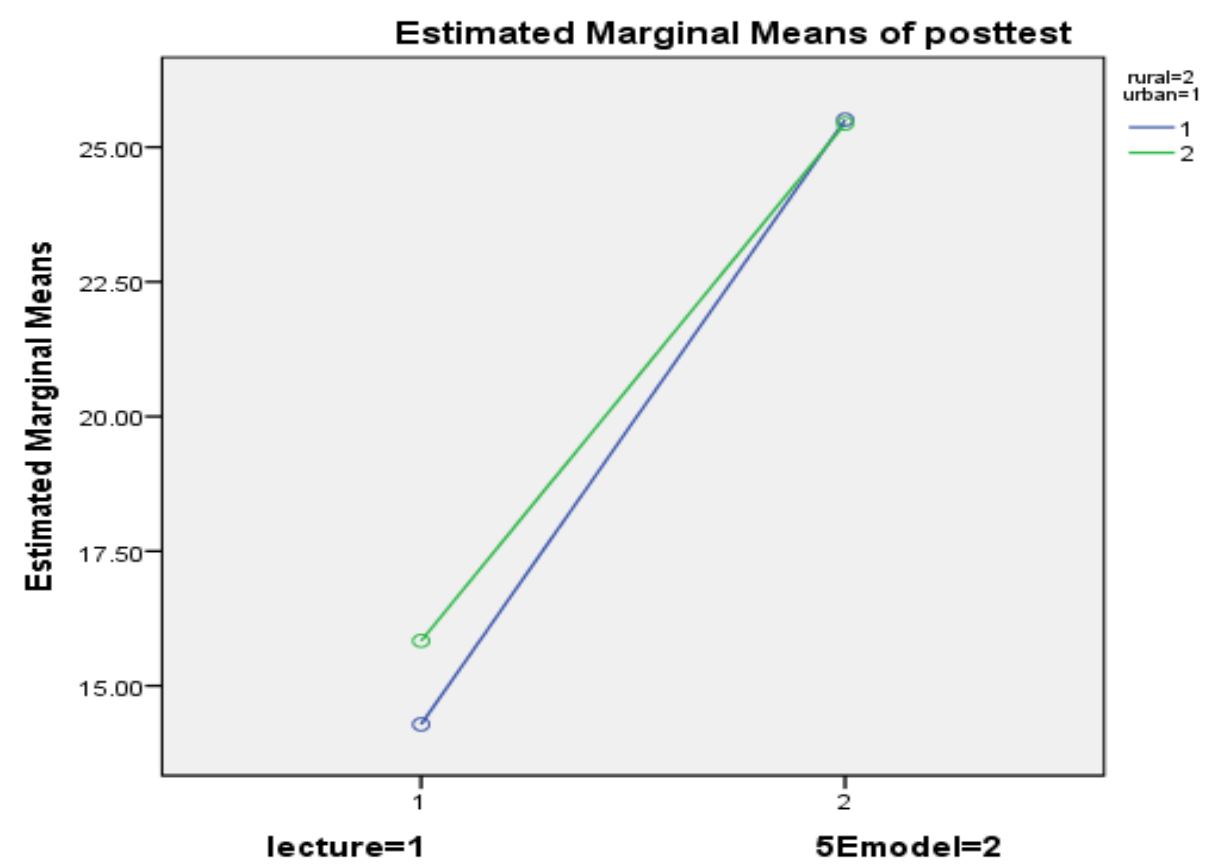

Covariates appearing in the model are evaluated at the following values: pretest $=8.7398$

Figure 1. Graph illustrating significance interaction effect between method and location on students' achievement in Physics. 


\subsection{Test of hypotheses}

This work examined the effects of school location on students' academic achievements based on the $5 \mathrm{E}$ learning cycle. The study also examined the interaction between the methods employed and school location.

Hypothesis 1 stated that there is no significant difference in the mean achievement scores of students in Physics between groups taught by using $5 \mathrm{E}$ learning cycle and those taught with lecture method. The mean score of the experimental group is higher than the mean score of the control group. This implies that the experimental ( $5 \mathrm{E}$ learning cycle) group achieved better than the control group. The $t$-test result ( $t$-cal. (18.315) $>t$-crit (1.960), p>0.005) shows difference in performance is significant. A confirmatory test using ANCOVA $(F(246)=360.591$, p>0.005) also confirms that the difference is significant in favour of the experimental group. Therefore, the achievement scores of students taught by using $5_{\mathrm{E}}$ learning cycle and those taught by using the lecture method in Physics is significantly different. This result is in consonance with Cardak et al. (2008), Cepni, Sahin \& Ipek (2010), Tuna \& Kacar (2013), Ajaja \& Eravwoke (2012), Qarareh (2012), Balci, Cakiroglu \& Tekkaya (2006) who reported a significant difference in students' achievement in favour of $5 \mathrm{E}$ learning cycle.

Hypothesis 2 stated there is no significant difference in the mean achievement scores in Physics between urban and rural students taught by using $5 \mathrm{E}$ learning cycle. The result of the descriptive statistics showed the mean achievement for rural and urban students in pre-test which were 8.87 and 9.18 respectively differ from the post-test scores of students which were 25.32 and 25.25. The descriptive statistics showed a difference in the mean achievement scores between rural and urban students. This implies that the rural students performed better than their urban counterparts. The finding establishes the fact that rural students are not disadvantaged when the $5 \mathrm{E}$ learning cycle is employed. However, when subjected to ANCOVA $(F(133)=0.004, \mathrm{p}>0.005)$, the difference was not significant. This led to the acceptance of the null hypothesis. This implies that the achievement of rural and urban students do not differ significantly when they are taught Physics by using the $5^{E}$ learning cycle. The result of Adjusted R Squared of 0.016 shows that the effect of school location on students' achievements based on $5 \mathrm{E}$ learning cycle is $1.6 \%$. The result on hypothesis 2 is at variance with the results of Adesoji and Olatunbosun (2008), Adepoju (2001), Ogunleye (2002), Ndokwu (2002), Owoeye (2002), Yusuf and Adigun (2010), Ajayi (1999) and Owoeye and Yara (2011). These researchers 
have observed that the achievements of students in urban and rural areas are significantly different.

In examining whether there is a significant difference in the mean achievement scores in Physics between urban and rural students taught by the lecture method, post-test scores of students showed that rural students scored 13.71; while urban students scored 15.67. On the basis of this result, it was established that there is a difference in the mean achievement scores in Physics between rural and urban students taught the use lecture method. The mean score of the urban students was higher than that of the rural students. This implies that urban students achieved better when the lecture method is employed. However, on exposure to ANCOVA ( $F$ $(113)=0.05, \mathrm{P}>0.05)$, the difference was not significant. This implies that there is no significant difference in achievement scores between rural and urban students when they are taught by the using lecture method. The result on the hypothesis is at variance with results of Adesoji and Olatunbosun (2008), Adopoju (2001), Ogunleye (2002), Ndokidu (2002), Owoeye (2002), Yusuf and Adigun (2010), Ajayi (1999) and Owoleye and Yara (2011) who reported significant difference in the achievement of students in urban and rural areas. This show with equal treatment, there will be no significant difference in the achievement between rural and urban students. Also, irrespective of the school location, the $5 \mathrm{E}$ learning circle improved the mean achievement of students.

The research also showed that there is no interaction effect between method and school location in students achievements in Physics. $F$ cal (2.178) < F-cal (3.84); p $>0.141$ show no significant interaction effect. Graphically, a dis-ordinal interaction between the lines crossed each other. This implies that the two factors did not interact to cause the desired test scores of the students. Thus, the null hypothesis of the non-significant interaction effect is established.

\section{Conclusion and Recommendation}

\subsection{Conclusion}

On the basis of the findings of this study, it is concluded that both methods (the lecture method and the $5 \mathrm{E}$ learning circle) improved students' achievement in Physics. However, the group exposed to $5^{\mathrm{E}}$ learning cycle achieved significantly better than the one taught with the traditional method. This study has established that the achievement of students taught by using both the lecture and the $5 \mathrm{E}$ 
learning circle did not differ significantly with school location (urban and rural). From the Adjusted R Square, the effect of school location on students' achievements in Physics based on the $5 \mathrm{E}$ learning cycle is just $1.6 \%$. Also, there is no interaction effect between method and school location in determining the achievements of students in Physics when the 5 E learning cycle is employed.

\subsection{Recommendations}

On the basis of the findings and conclusions of this study, the following recommendations are made:

1. The findings of the study have proved statistically the effectiveness of $5 \mathrm{E}$ learning cycle in enhancing better achievements in the learning of Physics. Thus, Physics teachers are encouraged to adopt the method in the teaching of the subject with a view to improving students' achievement in it. The method enables students to cooperate with one another and individual acquisition of knowledge instead of being spoon-fed. Using $5^{\mathrm{E}}$ learning cycle provides teachers with the opportunity to discover for themselves the individual problems of students and the general weakness of the students in the class.

2. Faculties of education of various institutions of higher learning should ensure that the $5 \mathrm{E}$ learning cycle is included as a method of teaching Physics and other science subjects. This will acquaint would-be teachers with the knowledge of the method and its advantages.

\section{References}

Abamba, E.I. (2012). Content coverage and students' academic achievement in senior secondary physics: The Delta State Example of Nigeria. Asia-Pacific Forum on science learning and teaching. 13(1), p2

Adams, K., Bevevino, M. \& Dengel, J. (1999). Constructivist theory in the classroom. The Clearing House, 117-120.

Adepoju, T. (2001). Location factors as correlates of private and academic performance of secondary schools in Oyo State. Unpublished Paper, UI, Ibadan.

Adesoji, F.A. \&Olatunbosun, S.M. (2008). Student, teacher and school environmental factor as determinants of achievement in senior secondary school chemistry in Oyo State, Nigeria. The Journal of International Social Research, 1(2).

Abdul, Q.S., Muhammad, N.Q., Khalid,J.S.\& Shalid, H.M. (2010). Teaching physics through learning cycle. An experimental study, 13(2):5-18.

Ajaja, O.P. (2013). Which Strategy best suit biology teaching? Lecturing, Concept mapping, cooperative learning or learning cycle? Electronic Journal of Science Education, 17(1). 
Ajaja, O.P. \& Eravwoke, U.O. (2012). Effects of $5 \mathrm{E}$ learning cycle on students on achievement in Biology and Chemistry. Cypriot Journal of Educational Sciences, 7(3). 244-262.

Ajayi, I.A. (1999). Unit cost of secondary education and students' academic achievement in Ondo State, Nigeria. Unpublished Ph.D Thesis, U.I.

Agbowaro, C. (2008). "The effects of metacognition on the meaningful learning of some biological concepts in secondary schools in Plateau State. Proceedings of the $49^{\text {th }}$ Annual Conference of the Science Teachers Association of Nigeria.

Akinyele O.A. (2011). Gender differences and school location factors as correlate of secondary school students' achievement in physics. The 2011 Maui International Academic Conference, Maui, Hawaii, USA 2011.

Akpan, E.U.U. (2001). Government and science and technology education in Nigeria. Journal of Educational Issues, 1(1): 101-113.

Arnold, M.L., Newman, J.H., Gaddy, B.B. \& Dean, C.B. (2000). A look at the condition of rural education research: setting direction for future research. Journal of Research in Rural Education, 2O(6). Retrieved from http://www.jrre.Psu.edu/articles/20-26pdf.

Balci, S., Cakiroglu, J. \& Tekkaya, C. (2006). Engagement, exploration, explanation, extension, and evaluation ( $5 \mathrm{E}$ ) learning cycle and conceptual change text as learning tool. Biochemistry and Microbiology Education, 34(3): 199-203

Bybee, R.W. (2011). The BSCS 5 E instructional model and $21^{\text {st }}$ century skills: A commissioned paper for a workshop on exploring the intersection of science education and the development of $21^{\text {st }}$ century skills. Retrieved 2014 from WWW.bscs.org.

Bybee, R.W., Taylor, J.A., Gardner, A., Scaffer, P.V., Powell, J.C., Westbrook, A. \&Landes, N. (2006). The BSCS 5E instructional model: Origins and effectiveness. WWW.bscs.org.

Caprio, M. W. (1994). Easing into constructivism, connecting meaningful learning with students' experience. Journal of College Science Teaching. 23(4), 210-212.

Cardak, O., Dikmenl, M. \& Saritas, O. (2008). "Effect of 5E instructional model in student success in primary school $6^{\text {th }}$ year circulatory system topic". Asian Pacific Forum on Science Learning and teaching, Vol. 9, Issue 2, Article 10.

Cepni, S., Sahin, C. \& Ipek, H. (2010).teaching floatation and sinking concepts with different method and technique based on the $5 \mathrm{E}$ instructional model. Asian Pacific Forum on Science Learning and teaching, Vol. 11, Issue 2, Article 5.

Eze, C.U. (2003). Effect of target task approach on students' achievement in senior school certificate physical chemistry. Proceedings of the $43^{\text {rd }}$ Annual Conference and Inaugural Conference of CASTME Africa.

$\mathrm{Hu}, \mathrm{S}$. (2003). Educational aspiration and postsecondary access and choice: Students in the urban, suburban and rural schools compared. Education Policy Analysis Archives, Vol. 11(14). http://epaa.asu. edu/epaa/v//n14/.

International Union of Pure and Applied Physics (IUPAP, 1999). www.triumf.iinfo/.../IUPAPAims.html. Retrieved 2011.

Keser, O.F. \& Akdeniz, A.R. (2010). Assessment of the constructivist physics learning environments. Asia-pacific Forum on Science Learning and Teaching, 11(1) article 6.

Macmillan, M. J. (2012). School Location versus academic achievement in Physics: Does computer-assisted instruction (CAI) has any effect? Journal of Educational and Social Research, 2(8): 162-168

Ndukwu, P.N. (2002). School and teacher factors as determinants of classroom material resources utilization in pre-primary school in Lagos State. Unpublished Ph.D Thesis.

Njoku, Z.C. (2002). Enhancing girls' acquisition of science process skills in co-educational

Ogunleye, A.O. (2002). Science education reform and its implications for the professional development of science teachers in Nigeria. Proceedings of the $43^{\text {rd }}$ Annual Conference and Inaugural Conference of CASTME Africa.

Ogunleye, B.O. \&Babajide, V.F.T. (2011). General instructional strategy enhances senior secondary school students' achievement in physics. European Journal of Educational Studies, 3(3): 453-455 
Okorodudu, R. I. (2013). Research methods and Statistics-A practical approach. University printing press, Delta State University, PMB 1, Abraka-Nigeria.

Okoronta, A.U. (2004). Model based instructional strategies as determinant of students' learning outcomes in secondary physics in Lagos State. An Unpublished Ph.D Thesis, UI, Nigeria.

Owoeye, J.S. \& Yara, P.O. (2011). School location and academic achievement of secondary schools in Ekiti State. Asia Social Science. Vol. 7

Owoeye, J.S. (2002). The effect of integration of location facilities and class size on academic achievement of secondary school students in Ekiti State, Nigeria. Unpublished Ph.D thesis, U.I.

Qarareh, A.O. (2012). The effect of using the learning cycle method in teaching science on the Educational achievement of the sixth graders. International Journal of Education Science, 4(2):123-132

Seyhan, H. \& Morgil, I. (2007). The effect of $5 \mathrm{E}$ learning model on teaching of acid-base topics in Chemistry education. Journal of Science Education, 8(2), 120-123.

Tuna, A. \& Kacar, A. (2013). The effect of 5 E Learning Model in teaching trigonometry on students' Academic Achievement and the permanence of their knowledge. International Journal on new trends in education and their implications. 4(1).

Yusuf, M.A. \& Adigun, J.T. (2010). The influence of school sex, location and type on students' academic performance. International Journal of Education Science, 2(2). 